MODEL DAKWAH KULURAL ZASTROUW AL-NGATAWI

Suciatie Sifa Endah Masdini

Prodi Pendidikan Agama Islam, Fakultasi Ilmu Sosial, Universitas Negeri Jakarta

E-mail: Suciaties123@gmail.com

\title{
Dewi Anggraeni
}

Prodi Pendidikan Agama Islam, Fakultas Agama Islam, Universitas Nahdlatul Ulama Indonesia

E-mail: dewianggraeni@unusia.ac.id

\section{Article Information}

Informasi Artikel

Naskah diterima : 15 Januari 2020

Naskah direvisi: 20 Februari Naskah disetujui : 3 Maret

Naskah dipublish: 10 April 2020

Keywords: Cultural

Da'wah, Zastrouw AlNgatawi, Culture.

Kata Kunci Dakwah

Kultural, Zastrouw AlNgatawi, Budaya

\section{Abstract}

Zastrouw Al-Ngatawi as the subject of this research has done something similar with Wali Songo, but the scope of activities carried out by Zastrouw Al-Ngatawi is more simple. The thing he did was one of the glory in Da'wah activities. This research is a qualitative descriptive. The subject in this study was Zastrouw Al-Ngatawi. Data collection methods used in this study were observation, interviews, and documentation. For analysis using Miles and Huberman's interactive analysis theory which includes data reduction (data reduction), presenting data (data display), and making conclusions or verification (conclusion drawing).

\section{Abstrak}

Zastrouw Al-Ngatawi sebagai subjek penelitian ini telah melakukan sesuatu hal yang sama dengan yang telah dilakukan Wali Songo, akan tetapi ruang lingkup kegiatan yang dilakukan Zastrouw Al-Ngatawi lebih simpel dan sederhana. Hal yang dilakukannya merupakan salah satu dari kejayaan dalam kegiatan dakwah. Penelitian ini merupakan penelitian deskriptif kualitatif. Adapun subjek dalam penelitian ini adalah Zastrouw Al-Ngatawi. Sedangkan metode pengumpulan data yang digunakan adalah observasi, wawancara, dan dokumentasi. Hasil penelitian ini menyimpulkan bahawa model dakwah kulttural Zastrow Al-Ngatawi dengan pendekatan budaya yakni dengan metode bil hikmah, materi mengandung muatan akidah, Syariah dan akhlak, serta mengandung berbagai macam nilai dakwah seperti keadilan, kejujuran, pengorbanan, tanggung jawab 


\section{PENDAHULUAN}

Kedatangan Islam ditengah-tengah kehidupan masyarakat bukan untuk menjadi tandingan dari kebudayaan yang telah berkembang di kehidupan masyarakat, melainkan sebagai upaya internalisasi ajaran agama Islam ke dalam budaya. Sebagaimana diketahui bahwa kehidupan masyarakat tidak dapat lepas dari pengaruh kebudayaan. Kebudayaan tidak hanya berpacu pada keyakinan dan kitab suci AlQur'an tetapijuga dipengaruhi oleh latar belakang seperti sejarah, geografis dan kondisi kehidupan sosial. Oleh karena itu, kebudayaan agama akan tumbuh dan berkembang sesuai dengan mekanisme kesejarahan.

Dalam kehidupan manusia, agama dan budaya jelas tidak berdiri sendiri, keduanya memiliki hubungan yang sangat erat dalam dialektikanya; selaras menciptakan dan kemudian salining menegaskan. Agama sebagai pedoman hidup manusia yang diciptakan oleh Tuhan. Sedangkan kebudayaan adalah sebagai kebiasaan tata cara hidup manusia yang diciptakan oleh manusia itu sendiri dari hasil daya cipta, rasa, dan karsanya yang diberikan oleh Tuhan. Agama dan budaya saling mempengaruhi satu sama lain. Agama mempengaruhi kebudayaan, kelompok masyarakat, dan suku bangsa. Kebudayaan cenderung berubah-ubah yang berimplikasi pada keaslian agama sehingga menghasilkan penafsiran berlainan.

Dakwah melalui pendekatan kebudayaan atau yang biasa dikatakan dengan dakwah kultural bertujuan untuk masyarakat mengetahui bahwa kebudayaan agama itu mengandung ajaran dan nilai-nilai budaya yang dapat diimplementasikan secara aktual dan fungsional dalam kehidupan sosial. Masyarakat saat ini mempunyai ghirah atau semangat dalam beragamanya tinggi maka banyak para da'i yang kemudian memanfaat momentum untuk berdakwah melalui pendekatan kultural. Masyarakat urban butuh akan kebutuhan spiritual maka dengan adanya kebutuhan spritual membuat masyarakat urban mengikuti kegiatan pengajian. Akan tetapi, pengajian tersebut terkadang tidak identik terhadap nilai-nilai budaya melainkan lebih kepada ideologi.

Dari sekian banyak pendakwah yang ada di Indonesia salah satu pendakwah yang berdakwah dengan pendekatan kultural ialah Zastrouw Al-Ngatawi, beliau merupakan seorang praktisi dakwah serta budayawan keagamaan yang terkenal di kalangan masyarakat Nahdlatul Ulama (NU) dengan ciri khas blangkon di kepalanya. Zastrouw Al-Ngatawi dalam kegiatan dakwah kulturalnya dengan menggunakan 
sesuatu yang menyenangkan atau idkholus surur salah satunya dengan melalui nilainilai budaya.

Berdasarkan latar belakang diatas, dapat dirumuskan beberapa permasalahan yang akan diteliti dalam penelitian ini meliputi sebagai berikut: (a) bagaimana metode dakwah kultural Zastrouw Al-Ngatawi? (b) bagaimana materi dakwah kultural Zastrouw Al-Ngatawi? (c) apa nilai-nilai budaya yang dilakukan oleh Zastrouw AlNgatawi?.

\section{METODOLOGI PENELITIAN}

Bentuk penelitian ini ialah penelitian kualitatif yakni penelitian lapangan yang bersifat deskriptif dan bertujuan untuk mengambarkan serta menjelaskan secara jelas dengan data-data yang kongkrit seperti hasil wawancara, observasi serta dokumentasi yang diperoleh di lapangan tentang model dakwah kultural Zastrouw Al-Ngatawi. Jenis penelitian ini ialah menggunakan pendekatan deskriptif kualitatif. Subjek yang akan diteliti pada penelitian ini ialah Zastrouw Al-Ngatawi dan objek penelitian ini adalah model dakwah kultural Zastrouw Al-Ngatawi. Untuk pengambilan data, penulis mendapatkannya melalui observasi, wawancara mendalam, dan dokumentasi.

\section{KAJIAN TEORI}

Model dakwah adalah sebuah pola maupun contoh dakwah yang diharapkan dapat menjadi pedoman bagi para pendakwah yang melakukan kegiatan dakwah sehingga dapat mencapai matlamat dakwah yang efektif dan efesien ${ }^{1}$. Media dakwah yaitu alat yang digunakan untuk menyampaikan materi dakwah (ajaran agama Islam) kepada objek dakwah atau mad'u.

Dakwah kultural adalah dakwah yang dilakukan dengan mengikuti berbagai budaya kultur masyarakat setempat tujuannya supaya dakwah dapat diterima oleh lingkungan masyarakat. Dakwah kultural juga dapat diartikan sebagai kegiatan dakwah dengan memperhatikan potensi dan kecenderungan masyarakat sebagai makhluk budaya secara luas dalam rangka menghasilkan kultur yang bernuasan Islam².

\footnotetext{
${ }^{1}$ Arifin, Za enal. (2007). Syi'ar Deddy Mizwar. Purwokerto: STAIN Purwokerto Press.

${ }^{2}$ Arifin, Muhammad. (2004). Psikologi Dakwah Suatu Pengantar Studi. Jakarta: Bumi Aksara.
} 
Dakwah kultural ialah pengembangan jalur dakwah dengan menggunakan jalur kultural, melalui jalur non formal misalnya melalui sebuah pengembangan kebudayaan, masyarakat, sosial dan bentuk non formal lainnya. (Samsul Munir Amin, 2008)

Nilai-nilai budaya merupakan Kajian tentang ilmu budaya dasar merupakan nilai-nilai dasar manusia, oleh sebab itu dalam proses pengkajiannya dibutuhkan pemahamannya yang luas. Hal tersebut merupakan sesuatu yang penting didalam kehidupan bermasyarakat. Dalam suatu kehidupan terdapat beberapa nilai budaya ataupun makna yang terdapat pada diri manusia dan lingkungan sekitarnya, antara lain sebagai berikut ${ }^{3}$ : a) Nilai keadilan b) Nilai kejujuran, c) Nilai tangung jawab, d) Nilai pengabdian, e) Nilai pengorbanan.

\section{METODE DAKWAH KULTURAL ZASTROUW AL-NGATAWI}

Dakwah kultural menurut Zastrouw Al-Ngatawi adalah dakwah yang menggunakan tradisi, seni dan budaya sebagai madzhad atau metode maupun alat dalam menyampaikan, menjelaskan dan mengajarkan ajaran-ajaran Islam kepada masyarakat. Dakwah kultural tidak hanya sekedar mengambil maupun mengutip potongan ayat Al-Qur'an, akan tetapi bagaimana teks tersebut dikontruksi dalam kehidupan sehari-hari.

Dakwah kultural yang dilakukan oleh Zastrouw Al-Ngatawi menggunakan metode Hikmah, yang dimana dalam kegiatan dakwahnya menaruh perhatian atau memfokuskan pada situasi, kondisi dan kapasitas yang dimiliki oleh para mad'u. Metode Hikmah dilakukan dengan melalui berbagai kegiatan, antara lain sebagai berikut:

\section{Keliling Bersama Sanggar Ki Ageng Ganjur}

Keliling bersama Sanggar Ki Ageng Ganjur dengan menggunakan musik untuk menjelaskan ajaran agama Islam. Penonton didalam konser religi terutama banyak dari kalangan anak-anak muda, pengemar musik atau pencinta musik dan lain-lain. Didalam kegiatan tersebut Zastrouw Al-Ngatawi bersama dengan Sanggar yang dipimpin olehnya melakukan kegiatan konser religi tersebut disela-sela konser itu Zastrouw AlNgatawi menjelaskan ajaran-ajaran agama Islam. Dalam penyampaian ajaran agama

\footnotetext{
${ }^{3}$ Prasetya, Joko Tri. (1991). Ilmu Budaya. Jakarta: PT Rineka Cipta.
} 
Islam yang pertama kali dijelaskan Zastrouw Al-Ngatawi terkait konteks akhlak dahulu.

Menurut Zastrouw Al-Ngatawi kegiatan dakwah harus idkholus surur atau menyenangkan hati. Zastrouw Al-Ngatawi juga membuat komunitas perkumpulan dari berbagai macam anak-anak pecintamusik dari kegiatan konser religi yang diadakannya. Komunitas tersebut diajarkan akhlak yang baik dan benar serta etika baik yang harus dimiliki seseorang dan seiring berjalannya proses nantinya konteks syariah akan berjalan sesuai tahapan-tahapan dalam berdakwah. Kegiatan konser religi yang diadakan oleh Zastrouw Al-Ngatawi bersama Sanggar Ki Ageng Ganjur sangat beraneka ragam antara lain ialah: "Perjalanan Spritual Iwan Fals dan Zastrouw AlNgatawi bersama Ki Ageng Ganjur ke Pesantren” di Pondok Pesantren Roudh loh AlTohiriyah, Kajen Margoyoso, Pati dan “Ngaji Bareng Slank feat Zastrouw Al-Ngatawi dan Ki Ageng Ganjur" di Pemalang.

Kegiatan konser religi yang dilakukan oleh Zastrouw Al-Ngatawi bersama Sanggar Ki Ageng Ganjur dapat dikatakan sebagai bagian dari dakwah karena didalam konser religi tersebut dilakukan dengan menggunakan lisan, tulisan, tingkat lagu dan lainnya serta konser yang diadakan mempunyai sebuah rencana untuk membuat para penonton, fans Iwan Fals dan fans Slank untuk datang mengikuti konser religi. Apabila dianalisis lebih jauh lagi, konser religi yang diadakan oleh Zastrouw Al-Ngatawi bersama Sanggar Ki Ageng Ganjur dapat dikategorikan sebagai dakwah bi al-hal karena didalam acara konser religi tersebut Zastrouw Al-Ngatawi terjun langsung dan melakukan aktivitas yang nyata seperti memberikan tanggapan mengenai syair-syair lagu Iwan Fals dan Slank. Konser religi ini secara aktual juga dirasakan oleh para penonton baik itu dari kalangan anak santri ataupun fans dari Iwan Fals dan Slank.

Kemudian konser religi yang dilakukan Zastrouw Al-Ngatawi bersama Sanggar Ki Ageng Ganjur dapat dikatakan sebagai dakwah kultural, karena konser tersebut memanfaatkan jalur kultur seperti alat-alat musik tradisional maupun modern sebagai upaya agar dakwah yang dilakukan mudah diterima dan menghasilkan kebudayaan yang bernuansa Islam. Sebab acara konser religi yang dilakukan diterima oleh para penonton. 
2. Keliling Mengunjungi Suatu Desa

Metode selanjutnya merupakan kegiatan yang dilakukan oleh Zastrouw AlNgatawi dalam mengajarkan serta menyebarkan ajaran agama Islam sesuai dengan kondisi dan tradisi kebudayaan di dalam lingkungan suatu desa. Mendatangi suatu desa yang memiliki potensi dari segi ekonomi. Salah satunya desadi daerah Lereng Merbabu yang merupakan desa yang subur dan makmur dalam segi ekonomi. Disana terdapat tradisi merti bumi, merti bumi merupakan tradisi yang dilakukan oleh masyarakat setahun sekali sebagai rasa syukur atas panen yang dihasilkan.

Disana melakukan open house, seluruh penduduk desa tersebut mengundang orang-orang sekitar dari mulai yang kenal ataupun yang tidak dikenal. Kegiatan merti bumi ini dilakukan penduduk desa dengan memberikan berbagai macam hiburan, makanan-makanan hasil dari panen dan diperbolehkan untuk menginap untuk masyarakat yang ingin menginap di desa tersbeut.

Dengan adanya tradisi merti bumi Zastrouw Al-Ngatawi menunggani atau menggunakan tradisi ini sebagai metode atau sarana dalam kegiatan dakwahnya. Dengan cara membuat acara-acara pengajian, tahlilan dan ziarah kubur. Diadakan kegiatan pengajian dan tahlilan agar dapat berbagi serta menambah pengetahuan dalam ilmu agama Islam, mempererat ikatan tali silahturahmi atau hubungan antara masyarakat penduduk desa, meningkatkan ketaqwaan serta keimanan dan mendoakan keluarga, kerabat maupun saudara yang sudah tiada.

Kegiatan Zastrouw Al-Ngatawi berkunjung kesebuah desa dengan tingkat ekonomi yang subur dan makmur dikatakan sebagai bagian dari dakwah karena didalam kegiatannya tersebut dilakukan secara sadar dengan mengajak masyarakat penduduk desa melakukan berbagai macam kegiatan terkait ajaran agama Islam. Apabila di analisis lebih jauh lagi, kegiatan Zastrouw Al-Ngatawi berkunjung kesuatu desa dapat dikategorikan sebagai dakwah bi al-hal karena didalam kegiatan tersebut sudah menggunakan perilaku atau aktivitas yang nyata dan kegiatan ini dapat dirasakan secara aktual oleh masyarakat penduduk desa.

Kemudian apabila kegiatan ini diklasifikasikan lagi pada unsur-unsur dakwah, kegiatan ini dikategorikan dalam metode hikmah karena didalam kegiatannya Zastrouw Al-Ngatawi menggunakan perhatiannya pada situasi dan keadaan yang ada pada lingkungan masyarakat penduduk desa tersebut dengan adanya tradisi merti bumi yang 
sudah dijalankan sejak lama disetiap tahunnya serta kegiatan dakwah Zastrouw AlNgatawi mengajak masyarakat penduduk desa melaksanakan perintah ajaran agama sesuai dengan Al-Qur'an dan Hadits.

Kegiatan yang dilakukan Zastrouw Al-Ngatawi dapat digolongkan sebagai bagian dari dakwah kultural, hal ini karena dakwah tersebut menggunakanjalur kultural dengan mengikuti tradisi kebudayaan masyarakat penduduk desa dalam rangka menjalankan kultur yang mempunyai nuansa Islam, dengan cara seperti itu merupakan usaha untuk menjaga tradisi kebudayaan yang sudah ada agar tidak terkisis oleh perkembangan zaman.

\section{Menghadirkan Acara Kajian}

Dalam kegiatan ini Zastrouw Al-Ngatawi menghadirkan sebuah kajian keagamaan yang di lakanakan oleh Islam Nusantara Center di Ciputat. Kegiatan Zastrouw Al-Ngatawi di acara Islam Nusantara Center tentang "Vernakularisasi Sebagai Tradisi Budaya Dalam Islam Nusantara" dan "Pesantren Sebagai Basis Kebudayaan Islam Nusantara" dikatakan sebagai bagian dari kegiatan dakwah karena di acara tersebut Zastrouw Al-Ngatawi melakukannya secara sadar mengajarkan kepada pada mad'u ntuk memahami serta mempelajari ajaran agama Islam dengan menggunakan lisan dan tingkah laku yang ditunjukkan oleh Zastrouw Al-Ngatawi. Apabila di analisis lebih jauh lagi, kegiatan Zastrouw Al-Ngatawi di acara Islam Nusantara Center dapat dikategorikan sebagai dakwah bi al- lisan karena Zastrouw AlNgatawi menggunakan lisannya untuk melakukan kegiatan ceramah dan melakukan dialog tentang ajaran agama Islam.

Kegiatan yang dilakukan Zastrouw Al-Ngatawi dapat digolongkan sebagai bagian dari dakwah kultural, hal ini disebabkan karena cara dakwah yang disampaikannyaa menggunakan jalur kultural dengan memberikan gambaran tentang tradisi kebudayaan seperti di era walisongo, yang dimana tembang lagu "Lir Ilir" merupakan bentuk vernakularisasi dalam sebuah teks yang di rekontruksi ulang kedalam teks ataupun kebudayaan yang bernuasan Islami, dengan menyanyikan tembang lagu tersebut dan menjelaskan satu persatu makna yang terkandung dalam lagu tersebut dalam konteks ajaran agama Islam dan menjalaskan tentang latar belakang kebudayaan yang dimiliki pesantren yang berbasis dari kebudayaa Islam Nusantara 
dengan cara mengambarkan proses transformasi yang dilakukan Walisongo serta strategi baru yang dilaukan oleh para ulama dan kiyai terhadap pesantren.

\section{MATERI DAKWAH KULTURAL ZASTROUW AL-NGATAWI}

Dakwah kultural Zastrouw Al-Ngatawi mengunakan materi Aqidah, Syariah, dan Akhlak melalui budaya. materi dakwah berisi tentang pesan-pesan ajaran agama Islam yang disampaikan oleh Zastrouw Al-Ngatawi secara menarik dan menyenagkan hati. Materi dakwah kultural Zastrouw Al-Ngatawi antara lain sebagai berikut:

1. Materi Dakwah Aqidah

Menurut Zastrouw Al-Ngatawi Kitab Al-Qur'an dan Hadits seperti gudang peluru. Apapun persoalan yang dialami di kehidupan, umat Islam mempunyai senjata pamungkas yang semuanya ada didalam kitab Al-Qur'an dan Hadits. Yang dimaksud dengan senjata pamungkas ini merupakan sebuah kitab yang paling ampuh dalam menyelesaikan maupun menjawab persoalan atau masalah sehingga kitab tersebut dapat berlaku menyelesaikan konsep kaidah sesuai persoalan yang ada di kalangan masyarakat. Akan tetapi dalam menggunakan senjata pamungkas ini tergantung cara penggunaan yang dilakukan yaitu tergantung pada masalah apa yang dihadapi dengan cara menggunakan alat senjata yang sesuai dengan masalah yang ada dan tergantung kecerdasan seseorang dalam menggunakan senjata pamungkas ini dalam memecahkan berbagai persoalan yang ada.

Menurut Zastrouw Al-Ngatawi khazanah teks Islam Nusantara tumbuh dengan karakter serta corak yang mempunyai khas Islam Nusantara. Teks Islam ini merupakan karya yang dimiliki oleh Islam Nusantara. Yang Saya heran orang-orang pada saat ini bikin teks kitab tidak bisa, akan tetapi mengakui dirinya yang sangat beriman, yang sangat Islam, yang sangat benar dan sangat hebat serta dengan mudahnya orang-orang tersebut mengkritiki sesuatu hal. Yang dimaksud kalimat diatas bahwa pada saat ini banyak sekali orang-orang yang mengakui dirinya paling benar, yang paling beriman sehingga timbuh perilaku mudahnya mengklaim seseorang yang dilihat salah dan mengkritiknya dengan dasar y ang belum tentu benar. Islam Nusantara mempunyai teks Islam yang bercorak serta memiliki karakter yang tumbuh di Nusantara. 


\section{Materi Dakwah Syariat}

Materi dakwah syariat merupakan materi yang memiliki hubungan erat dengan amal nyata dalam menjalankan perintah ajaran agama Islam dalam dua aspek yaitu aspek ibadah seperti shalat, puasa, zakat atau bersedekah dan sebagainya serta aspek muamalah seperti sesuatu ketetapan hukum yang diperintahkan oleh Allah SWT.

Menurut Zastrouw Al-Ngatawi bahwa suatu kepantasan itu menjadi penting, bukan hanya sah tidak sah, boleh atau tidak boleh, akan tetapi pantas atau tidak pantas. Jika ukuran boleh tidak boleh, ketika mengerjakan shalat menggunakan celana pendek sudah boleh dan sudah tertutup. Tapi apakah hal tersebut pantas. Yang dimaksud dalam kalimat di atas bahwa memang ketika dalam mengerjakan ibadah shalat diperbolehkan menggunakan celana yang sudah menutupi auratnya akan tetapi ketika ingin beribadah menghadap Allah apakah kita pantas menggunakan pakaian celana tersebut, sepantasnya saat beribadah kepada Allah menggunakan pakaian yang benar-benar pantas seperti menggunakan pakaian sarung.

Menurut Zastrouw Al-Ngatawi bahwa dalam bersedekah dengan munculnya sikap individualisme belum tentu sedekah dikerjakan karena adanya wujud empati. Seseorang menjadikan orang miskin yang akhirnya dijadikan sebagai objek dalam pencaharian pahala saja. Inilah yang terjadi saat ini karena dampak dari formalisme agama yang orang beragama tidak sampai hatinya kalau dia beragama tidak sampai hatinya dan pada akhirnya tidak ada wujud empati. Yang dimaksud kalimat diatas bahwa ketika seseorang sudah mempunyai atau memiliki sikap individualisme dalam bersekedah, hal ini dapat menyebabkan hilangnya wujud rasa empati terhadap sesama manusia. Karena ketika melakukan sedekah akan menjadikan seorang yang menerima sedekah menjadi sebuah objek atau sasaran dalam mencari sebuah pahala tanpa melihat wujud empati antar sesama manusia.

\section{Materi Dakwah Akhlak}

Materi dakwah akhlakmerupakan materi terkait tata cara maupun tindakan yang nyata antara manusia dengan Tuhan, manusia dengan manusia, manusia dengan hewan dan manusia dengan alam semesta. Materi akhlak dakwah kultural yang dilakukan oleh Zastrouw Al-Ngatawi antara lain sebagai berikut: 
a) Lagu Hidup

Dakwah kultural Zastrouw Al-Ngatawi mengunakan materi Akhlak dengan melalui budaya, yang berhubungan dengan tata cara berhubungan kepada Allah dan kepada seluruh makhluk ciptaan Allah seperti manusia, hewan, tumbuhan dan lain -lain. Bersumber dari Al-Qur'an dan hadits yang diimpelementasikan kedalam kehidupan sehari-hari dengan berazazkan pada agama dan budaya karena agama dan budaya menjadi satu kesatuan.

Menurut Zastrouw Al-Ngatawi bahwa lagu hidup adalah akhlak serta praktik kehidupan, bukan semata-mata hanya pendekatan tekstualis itu teksnya dibunyikan, dalilnya dibunyikan dan hanya terpaku pada teks. Yang dimaksud dari istilah lagu hidup ini adalah praktik kehidupan dengan nilai-nilai kebudayaan yang merupakan sebuah materi akhlak dengan bersumber dari teks Al-Qur'an dan Hadits ataupun teks ajaran agama Islam. Lagu hidup ini menjadikan suatu kontruksi kebudayan yang di praktikan kedalam kehidupan yang bersumber dari teks Al-Qur'an dan hadits.

Salah satu contoh materi akhlak yang diberikan oleh Zastrouw Al-Ngatawi terdapat pada konser religi "Ngaji Bareng Slank feat Zastrouw Al-Ngatawi dan Ki Ageng Ganjur” di Pemalang. Didalam kegiatan konser tersebut Zastrouw Al-Ngatawi mengajarkan bahwa pada diri manusia hendaklah menjadi orang yang saling peduli terhadap sesama manusia dan juga peduli terhadap lingkungan sekitar. Karena dikehidupan ini terdapat virus yang dapat memecah belah peratuan dan hubungan antar umat.

Dengan meggunakan materi Akhlak yang dilakukan oleh Zastrouw Al-Ngatawi tersebut dikatakan sebagai bagian dari strategi dakwah kultural karena Zastrouw AlNgatawi dalam kegiatannya memberikan suatu pemahaman dan arah an tentang ajaran agama Islam kepada anak-anak tersebut sesuai dengan kapasitas dan kebutuhan yang dimiliki. Kebutuhan yang diberikan Zastrouw Al-Ngatawi adalah praktik kehidupan dalam konteks akhlak dengan menggunakan kebudayaan.

b) Budaya Jawa

Zastrouw Al-Ngatawi memberikan berbagai macam contoh tekait materi akhlak dengan menggunakan kebudayaan jawa yang dilakukannya antara lain yaitu pertama, kegiatan slametan pada zaman dulu slametan merupakan penyembahan pada dewadewa dan makhluk ghaib, hal ini dalam konteks sembahan pada dewa-dewa dan 
makhluk ghaib ini dihilangkan menjadi sarana untuk memperkenalkan tuhan dengan cara membacakan kalimat-kalimat tauhid dan membaca ayat suci Al-Qur'an. Serta penyembahan pada dewa-dewa dan makhluk ghaib diganti menjadi kegiatan bersedekah.

Kedua, pada zaman dulu terdapat masyarakat paguyuban, hal ini bagian dari kontruksi kebudayaan yang dijadikan sebagai hubungan antara sesama makhlukmakhluk ciptaan Allah dengan cara membuat kelompok shalawatan, kelompok slametan, tradisi munggahan dan lain sebagainya. Kebudayaan yang sudah ada tidak dirusak, akan tetapi dijadikan sebagai sebuah strategi pendekatan dalam menyebarkan ajaran agama Islam. Contoh-contoh tersebut digunakan sebagai stategi pendekatan dakwah kultural oleh Zastrouw Al-Ngatawi dalam kegiatan dakwahnya.

Zastrouw Al-Ngatawi dalam kegiatan dakwah menggunakan materi akhlak tersebut dapat dikatakan sebagai bagian dari strategi dakwah kultural karena Zastrouw Al-Ngatawi menggunakan suatu kebudayaan jawa yang sudah ada sejak lama sebagai sarana dalam kegiatan berdakwahnya. Kegiatan yang dilakukannya memberikan dan mengajarkan tentang pemahaman ajaran agama Islam sesuai aspek kebutuhan masyarakat serta kegiatan yang dilakukan oleh Zastrouw Al-Ngatawi berlandarkan pada kemampuan yang dimiliki olehnya.

NILAI-NILAI BUDAYA DALAM DAKWAH KULTURAL ZASTEOUW ALNGATAWI

Menurut Zastrouw Al-Ngatawi bahwa Zastrouw Al-Ngatawi tidak menanamkan nilai secara formal, akan tetapi kami mengeksplorasi nilai-nilai budaya yang sudah ada seperti nilai kejujuran, nilai kearifan, nilai empati dan lainnya. Zastrouw Al-Ngatawi didalam dakwah kultural yang dilakukannya ia mengeksplorasi nilai-nilai kebudayaan yang sudah ada, nilai-nilai budaya tersebut antara lain sebagai berikut:

1. Nilai Kejujuran

Nilai kejujuran merupakan sebuah nilai yang dilakukan atas dasar kesadaran yang lahir maupun dimiliki seseorang individu dari hati nurani dengan kenyataan yang ada. Menurut Zastrouw Al-Ngatawi bahwa Zastrouw Al-Ngatawi lebih baik pakai gitar bolong daripada pakai uang hasil korupsi. walaupun menggunakan gitar bolong akan tetapi hasil yang didapatkan adalah hasil yang halal. 
Kalimat diatas menjelaskan bahwa lebih baik menjadi seorang musisi jalanan daripada menjadi seorang yang korupsi. Karena walaupun musisi jalanan sering kali terlihat sebagai orang yang tidak jelas kehidupannya akan tetapi yang dihasilkan dari menjadi musisi jalanan merupakan hasil pekerjaan yang jujur dengan mendapatkan hasil yang halal.

Sedangkan seorang korupsi walaupun dalam segi penampilan terlihat rapih dan perkataan yang dikatakannya sering kali terdengar manis akan tetapi seorang korupsi merupakan orang yang tidak jujur serta hasil yang didapatkannya merupakan hasil yang tidak baik atau haram. Oleh sebab itu, menjadi seorang yang jujur merupakan suatu kewajiban yang patut untuk dimiliki oleh semua kalangan masyarakat.

\section{Nilai Keadilan}

Nilai keadilan merupakan nilai suatu perilaku yang mempunyai keseimbangan antara kewajiban serta hak dalam kehidupan individu maupun kehidupan kelompok masyarakat sebagai makhluk ciptaan Tuhan. Menurut Zastrouw Al-Ngatawi bahwa lagu yang dibawakan slank mengingatkan kita untuk menjadi orang yang baik dalam memperjuangkan keadilan harus dengan maju terus pantang mundur sebagai generasi muda penerus bangsa.

Kalimat diatas menjelaskan bahwa sebagai masyarakat Indonesia yang menjadi generasi penerus bangsa wajib serta harus menjadi orang yang adil dalam memperjuangkan kewajiban dan hak masyarakat Indonesia. Sebagai generasi penerus bangsa dalam menerapkan nilai keadilan harus maju dan pantang menyerah demi menjaga kerukunan antar masyarakat di Indonesia.

Sikap keadilan dalam konteks ini merupakan sikap sosial masyarakat yang menjadikan kewajiban dan hal sebagai bentuk sikap keadilan dalam bermasyarakat dan berbangsa. Walaupun di Indonesia mempunyai banyak suku, ras dan budaya tidak menghalangi generasi penerus bangsa untuk menegakkan nilai keadilan di Indonesia.

3. Nilai Tanggung Jawab

Nilai tangung jawab merupakan nilai yang dimiliki seseorang dengan kesadaran pada diri sendiri terhadap perilaku yang ada di lingkungan sekitarnya yang dapat dirasakan oleh manusia itu sendiri. Menurut Zastrouw Al-Ngatawi dalam kegiatan konser religinya bahwa karena tugas menanam serta memelihara tanaman melangsungkan kehidupan, dan juga dijelaskan dalam ayat-ayat Al-Qur'an bahwah 
telah tampak kerusakan di bumi dan di lautan karena ulah tangan manusia yang tidak merawat alam ini dengan baik dan benar. Kita harus menyiram dan menanam tanaman.

Zastrouw Al-Ngatawi menjelaskan pada kalimat diatas dalam kegiatan konser religi bahwa manusia dalam dirinya harus menamkan nilai tangung jawab, salah satu gambaran di kehidupan tentang nilai tangung jawab ialah terhadap tumbuh-tumbuhan yang ada di muka bumi ini. Karena dengan menanam dan merawat tumbuhan dapat menjaga kelestarian alam dimuka bumi. Oleh sebab itu, sebagai manusia yang hidup dan tinggal dibumi ini wajib menjaga keindahan alam dengan cara merawat dan menjaga tumbuh-tumbuhan yang ada dilingkungan sekitar

4. Nilai Pengorbanan

Nilai pengrobanan merupakan nilai yang muncul dalam bentuk pemikiran, tenaga, harga, benda serta perasaan yang dimiliki seseorang secara sadar dan secara ikhlas tanpa mengharapkan segala bentukbalasan dari siapapun. MenurutZastrouw AlNgatawi dalam kegiatan konser religi bahwa saat ini terdapat virus yang jahat yaitu virus yang memecah belah kesatuan dan virus keruntuhan bangsa. Kita juga harus bertangung jawab atas kesatuan dan kerukunan NKRI serta pengorbanan seorang ibu sebagai orang tua kita, berjalan beribu-ribu kilo meter demi seorang anak supaya dapat hidup sejahtera dengan kasih sayang yang diberikannya.

Kalimat diatas menjelaskan bahwa sebagai warga negara Indonesia harus mengorbankan yang dimiiki untuk menjaga persatuan dan kesatuan NKRI dalam kehidupan bermasyarakat. Dan juga dijelaskan oleh Zastrouw Al-Ngatawi dalam konser religi "Perjalanan Spritual Iwan Fals dan Zastrouw Al-Ngatawi bersama Ki Ageng Ganjur ke Pesantren”. Bahwa seorang orang tua rela mengrobankan kehidupannya dengan banting tulang untuk menghidupi keluarganya dalam kondisi apapun. Orang tua rela melakukan apa saja demi keluarga yang dicintainya. Oleh sebab itu, manusia patut berjuang dalam mengorbankan segala sesuatu yang ingin dilindunginya serta sesuatu yang ingin dimilikinnya.

Nilai-nilai yang dilakukan oleh Zastrouw Al-Ngatawi merupakan hal yang penting dalam dakwah kultural. Menurutnya terkadang atas nama agama atau atas nama kebenaran banyak orang yang mengorbankan nilai-nilai budaya. Akan tetapi jika dalam segi kebudayaan, nilai-nilai budaya tersebut dikembangkan sebagai strategi dalam melakukan kegiatan dakwah kultural. 
Zastrouw Al-Ngatawi memberikan sebuah contoh cerita tentang akhlak bagus yang menggunakan nilai-nilai budaya dalam kehidupannya. Ada seorang kiyai yang bernama Kiyai Hudori, beliau merupakan ulama besar di tegalrejo magelang singkat cerita suatu hari beliau kedatangan seorang lurah yang sedang merasakan kebingungan. Seorang lurah tersebut habis menjual tanah milik desa dan warganya mengalami konflik karena sebagian dari warga ingin uang hasil penjualan tanah desa dipakai untuk membuat masjid dan sebagain warganya yang lain ingin hasil penjualan tersebut digunakan untuk membeli alat musik gamelan karena kebetulan ada penjual yang menjual alat musik gamelan dengan harga yang murah.

Singkat cerita dengan kejadian tersebut Kiyai Hudori memerintahkan kepada lurah bahwa hasil yang didapatkan dari penjualan tanah desa agar dipakai untuk membeli alat musik gamelan. Alasan mengapa Kiyai Hudori lebih membeli alat musik gamelan dari pada membangun masjid karena beliau lebih mengutamakan solidaritas, keutuhan, kebersamaan, kedamaian antara umat manusia. Perilaku yang dilakukan oleh Kiyai Hudori ini menggabarkan dakwah dengan pendekatan nilai-nilai budaya.

Diberbagai kegiatan yang dilakukan oleh Zastrouw Al-Ngatawi banyak sekali ajaran-ajaran dengan menitik beratkan pada nilai-nilai budaya antara lain yaitu pada konser religi yang diadakannya bersama dengan Iwan Fals dan juga Slank. Zastrouw Al-Ngatawi menghibau untuk para OI (Orang Indonesia) dan Slanker dalam menjalankan kehidupan bermasyarakat harus menanamkan nilai-nilai budaya pada diri sendiri salah satunya dengan cara melakukan sesuatu hal dengan jujur tidak boleh curang atau berbohong, peduli kepada seseorang disekitar, mempererat persatuan dan kesatuan NKRI, dan menjaga ketentraman acara konser religi dengan aman agar semua penonton merasakan kesenangan.

Kegiatan dakwah yang dilakukan oleh Zastrouw Al-Ngatawi jika dianalisis lebih mendalam lagi dapat dikategorikan nilai-nilai budaya yang diterapkan ilalah nilai kejujuran serta nilai tangung jawab, hal ini disebabkan dalam beberapa kegiatan yang dilakukan menampakkan nilai-nilai tersebut salah satunya seperti pada kegiatan keliling bersama Sanggar Ki Ageng Ganjur, Zastrouw Al-Ngatawi memcontohkan secara aktual dan terorganisis dalam membawakan kegiatan keliling tesebut dan membuat skenario pada kegiatan konser religi bersama Sanggar Ki Ageng Ganjur. Apabila dianalisis lebih jauh kegiatan yang dilakukan oleh Zastrouw Al-Ngatawi 
mengandung sifat-sifat budaya yang beraneka ragam kebudayaan, karena nilai-nilai kebudayaan yang diberikan atau ditampilkan Zastrouw Al-Ngatawi menyesuaikan dengan kebutuhan para penonton konser tersebut.

\section{KESIMPULAN}

Berdasarkan hasil penelitian di lapangan dan kajian pustaka yang terdapat di bab sebelumnya, maka peneliti dalam bagian akhir ini dapat mengambil beberapa kesimpulan antara lain sebagai berikut:

1. Metode dakwah kultural yang dilakukan oleh Zastrouw Al-Ngatawi menggunakan metode Hikmah, dengan memfokuskan kepada situasi, kondisi serta kapasitas yang dimiliki oleh para mad'u. Serta menaruh perhatian pada lingkungan disekitar kehidupan para mad'u. Metode dakwah kultural yang dilakukan antara lain sebagai berikut:

a) Keliling bersama Sanggar Ki Ageng Ganjur, dengan melalui kegiatan konser religi salah satunya dengan melakukan kolaborasi bersama artis Indonesia seperti Iwan Fals dan SLANK.

b) Keliling mengunjungi suatu desa yang mempunyai potensi di bidang ekonomi, salah satu desa yang dikunjungi berada di daerah Lereng Merbabu, dengan menggunakan serta mengikuti tradisi kebudayaan yang sudah ada masyarakat penduduk desa tersebut yaitu tradisi “merti bumi” sebagai metode dalam kegiatan dakwah kultural. Dengan cara mengadakan kegiatan pengajian, tahlilan dan ziarah kubur.

c) Menghadirkan acara, salah satu yang dihadiri Zastrouw Al-Ngatawi adalah kajian keagamaan yang diselenggaraan oleh Islam Nusantara Center di Ciputat, salah satu tema kajiannya ialah "Vernakularisasi Sebagai Tradisi Budaya Dalam Islam Nusantara" dan "Pesantren Sebagai Basis Kebudayaan Islam Nusantara".

2. Materi dakwah kultural yang digunakan Zastouw Al-Ngatawi antara lain ialah sebagai berikut:

a) Materi Aqidah dengan meliputi lima rukun iman tentang beriman kepada kitab suci Al-Qur'an dan Hadits yang dijadikan sebagai gudang senjata pamungkas dalam menjalankan permasalahan kehidupan di masyarakat. 
b) Materi Syariat dengan memiliki hubungan erat dengan amal nyata dalam menjalankan perintah ajaran agama Islam dalam kepantasan dalam melakukan ibadah sholat kepada Allah SWT dan kegiatan bersedekah dengan dengan wujud rasa empati kepada sesama manusia.

c) Materi Akhlak melalui budaya, dengan mengajarkan tentang tata cara berhubungan kepada Allah, manusia, tumbuhan, hewan dan ciptaan Allah lainnya yang bersumber dari Al-Qur'an dan hadits, antara lain ialah:

a. Lagu hidup atau praktik kehidupan, yaitu dijadikan sebagai suatu kontruksi kebudayaan yang di praktikan kedalam kehidupan masyarakat.

b. Budaya jawa, yaitu menggunakan tradisi kebudayaan jawa salah satunya kegiatan slametan yang pada zaman dulu kegiatan tersebut merupakan penyembahan terhadap dewa-dewa dengan mengantikan konteks sembahan menjadi penyembahan kepada Allah dengan membaca kalimat-kalimat tauhid dan lain sebagainya.

3. Nilai-nilai budaya dalam dakwah kultural Zastrouw Al-Ngatawi

a) Nilai kejujuran, yaitu lebih baik menjadi seorang musisi jalanan daripada menjadi seorang koruptor karena menjadi seorang musisi jalanan merupakan perilaku yang jujur serta mendapatkan hasil yang halal.

b) Nilai keadilan, yaitu masyarakat Indonesia perlu menjadi orang yang adil untuk memperjuangkan kewajiban dan hak asasi manusia.

c) Nilai tangung jawab, yaitu di muka bumi ini manusia mempunyai tangung jawab dalam menjaga kelestarian alam dengan menjaga keindahan serta merawat atau menjaga tumbuh-tumbuhan yang ada di bumi.

d) Nilai pengorbanan, yaitu masyarakat Indonesia perlu mengorbankan dirinya dalam menjaga persatuan dan kesatuan NKRI didalam kehidupan sosial dan dalam konteks hubungan keluarga orang tua mengorbankan dirinya agar dapat menghidupi keluarganya dalam kondisi apapun. 


\section{DAFTAR PUSTAKA}

Amin, Samsul Munir. (2009). Ilmu Dakwah. Jakarta: Amzah.

Amin, Samsul Munir. (2008). Rekontruksi Pemikiran Dakwah Islam. Jakarta: Amzah.

Arifin, Muhammad. (2004). Klasifikasi Ayat-Ayat Al-Qur'an Dakwah Kontemporer Buku Cerdas Para Dai. Surabaya: Pustaka Agung Harapan.

Arifin, Muhammad. (2004). Psikologi Dakwah Suatu Pengantar Studi. Jakarta: Bumi Aksara.

Aziz, Moh Ali. (2016). Ilmu Dakwah. Jakarta: Prenadamedia Group.

Ilaihi, Wahyu. (2010). Komunikasi Dakwah. Bandung: Remaja Rosdakarya.

Prasetya, Joko Tri. (1991). Ilmu Budaya. Jakarta: PT Rineka Cipta.

Saerozi. (2013). Ilmu Dakwah. Yogyakarta: Penerbit Ombak.

Widagdho, Djoko. (1994). Ilmu Budaya Dasar. Jakarta: Bumi Aksara.

Arifin, Zaenal. (2007). Syi'ar Deddy Mizwar. Purwokerto: STAIN Purwokerto Press.

Zaenal Ari $\square$ n. (2007). Syi’ar Deddy Mizwar. Purwokerto: STAIN Purwokerto

Press.

Zaenal Ari $\square$ n. (2007). Syi’ar Deddy Mizwar. Purwokerto: STAIN Purwokerto

Press

\section{JURNAL}

Abdul Wahid, 'Dakwah Dalam Pendekatan Nilai-Nilai Kearifan Lokal (Tinjauan Dalam Perspektif Internalisasi Islam Dan Budaya)', Jurnal Dakwah Tabligh, 19.1 (2018), 1-19<https://doi.org/10.24252/jdt.v19i1.5908>.

Laode Monto Bauto, 'Perspektif Agama dan Kebudayaan Dalam Kehidupan Masyarakat Indonesia (Suatu Tinjauan Sosiologi Agama', JPIS, 23.2 (2014), 11-25

Nur Ahmad, 'Mewujudkan Dakwah Antar Budaya Dalam Perspektif Islam', AtTabsyir, 3.1 (2015), 21-40.

Syabuddin Gade dan Abdul Ghafar Hj Don, 'Model Dakwah: Satu Analisis Teoritikal', Ulum Islamiyyah Journal, 16.1 (2015), 23-41. 
Model Dakwah Kulural ZastrouwAl-Ngatawi 